\title{
PEMETAAN DAERAH PENANGKAPAN HANDLINE DENGAN BASIS PENANGKAPAN IKAN DI KECAMATAN GALESONG SELATAN KABUPATEN TAKALAR
}

\section{MAPPING OF HANDLINE FISHING GROUND WITH FISHING BASE IN MANGINDARA VILLAGE, SOUTH GALESONG SUBDISTRICT, TAKALAR DISTRICT}

\author{
Sudarmintha*), Mukti Zainuddin, Safruddin \\ Program Studi Pemanfaatan Sumberdaya Perikanan, Fakultas Ilmu Kelautan dan Perikanan, Universitas \\ Hasanuddin
}

Diterima: 05 Januari 2019; Disetujui: 18 Februari 2019

\begin{abstract}
ABSTRAK
Rendahnya efektivitas pengoperasian alat tangkap yang beroperasi di perairan Selat Makassar tidak terlepas dari masalah keterbatasan informasi mengenai fishing ground pancing ulur yang tepat. Penelitian ini bertujuan untuk melihat karakteristik oseanografi, dan memetakan lokasi sebaran fishing ground pancing ulur yang beroperasi di perairan Selat Makassar serta mendeskripsikan distribusi hasil tangkapan pancing ulur pada setiap zona penangkapan ikan. Penelitian ini dilakukan pada bulan April sampai Juni 2018 di perairan bagian Selatan Selat Makassar dengan jumlah sampel 42 titik. Hasil penelitian menunjukkan daerah fishing ground pancing ulur yang beroperasi di perairan selatan Selat Makassar terbagi dalam 3 zona yakni sekitar perairan Pulau Tanakeke (zona I), Karang Bone Laisi (zona II) dan Karang Masalima (zona III) dengan sebaran karakteristik oseanografi yang masing-masing berbeda pada setiap zona penagkapan yang diakibatkan oleh perbedaan letak geografis. Distribusi hasil tangkapan pada setiap zona ditemukan turut memiliki perbedaan dari aspek dominasi spesies maupun ukuran tangkapan. Adapun jenis tangkapan yang dominan tertangkap pada setiap zona penangkapan terdiri atas jenis Butterfly Whiptail (zona I), Spotcheek Emperor (zona II) dan Longface Emperor (zona III).
\end{abstract}

Kata Kunci: Pemetaan, Oseanografi, Tangkapan, Pancing Ulur, Zonasi

\begin{abstract}
The low effectiveness of fishing gear operating in the waters of the Makassar Strait is inseparable from the problem of limited information about fishing ground of handline. This study aims to look at oceanographic characteristics, and map the location of handline's fishing ground operating in the waters of the Makassar Strait and describe the distribution of handline fishing catches in each fishing zone. This research was conducted in April through June 2018 in the waters of the southern part of the Makassar Strait with 42 points sample. The results showed that the area handline fishing in the waters south of the Makassar Strait was divided into 3 zones, namely around the waters of Tanakeke Island (zone I), Bone Laisi reef (zone II) and Masalima Reef (zone III) with the distribution of oceanographic characteristics is different of each catchment zone that caused by differences in geographical location. The distribution of catches in each zone is found the differences in species dominance and catch size. The dominant types of catches in each catchment zone consist of Butterfly Whiptail (zone I), Spotcheek Emperor (zone II) and Longface Emperor (zone III).
\end{abstract}


Keywords: Mapping, Oceanography, Catches, Handline, Zoning

\begin{tabular}{ll}
\hline Contact person & : Sudarmintha \\
E-Mail & : sudarminthafikp@gmail.com
\end{tabular}

\section{PENDAHULUAN}

Sektor perikanan tangkap di Kabupaten Takalar merupakan salah satu sektor yang memegang peranan penting bagi kesejahteraan masyarakat di daerah tersebut. Menurut Said (2015) hasil perikanan di Kabupaten Takalar, Provinsi Sulawesi Selatan telah memberikan kontribusi yang cukup besar bagi produksi perikanan dan kelautan di Sulawesi Selatan. Kabupaten Takalar yang berada di daerah pesisir Pantai Selat Makassar adalah salah satu sentra produksi perikanan andalan bersama beberapa daerah lainnya di Provinsi Sulawesi Selatan, di antaranya Kabupaten Barru, Pinrang, Sinjai, dan Selayar.

Tingginya ketergantungan masyarakat Kabupaten Takalar pada sektor perikanan ditandai dengan adanya peningkatan upayaupaya yang dilakukan untuk meningkatkan produksi hasil perikanan. Pada sektor perikanan tangkap sendiri, peningkatan upaya ditandai dengan kemunculan berbagai macam tipe alat penangkapan ikan dengan target tangkapan dan metode pengoperasian yang berbedabeda.

Terdapat 9 jenis kapal perikanan di Kabupaten Takalar yang dikelompokkan berdasarkan jenis alat tangkap yang dioperasikan yaitu Multi Purpose A, kapal Multi Purpose B, kapal Multi Purpose C, kapal Multi Purpose D, kapal Bubu, kapal Handline, kapal Gillnet, kapal Purse seine dan cantrang (Nahdyah dkk, 2014).
Pancing ulur merupakan salah satu jenis alat tangkap yang banyak dioperasikan oleh nelayan di Galesong Selatan, saat ini jumlahnya diperkirakan mencapai sekitar 60 unit. Peningkatan jumlah unit penangkapan di lokasi tersebut saat ini tidak berbanding lurus dengan angka produksi yang dihasilkan. Hal ini mengindikasikan bahwa laju ekspolitasi tidak seimbang dengan daya dukung lingkungan.

Penelitian tentang alat tangkap pancing ulur telah banyak dilakukan oleh peneliti sebelumnya antara lain (Oktaviani, 2013) yang meneliti pengaruh perbedaan konstruksi mata pancing dan jenis umpan terhadap hasil tangkapan, (Pangalila, 2015) status hasil tangkapan perikanan pancing dasar di perairan Teluk Buyat dan Nurhayati (2006) meneliti pengaruh kedalaman terhadap komposisi hasil tangkapan pancing ulur di Palabuhanratu.

Sejauh ini belum ditemukan kajian khusus tentang letak dan karakteristik daerah penangkapan alat tangkap handline yang berbasis di Kecamatan Galesong Selatan Kabupaten Takalar. Sementara informasi tersebut dinilai penting sebagai penunjang keberhasilan usaha penangkapan ikan dengan pancing ulur serta sebagai acuan dalam pengelolaan sumberdaya perikanan bertanggung jawab.

Adapun tujuan penelitian ini yakni sebagai berikut: Memetakan zonasi wilayah pengoperasian pancing ulur yang berbasis di Galesong Selatan Kabupaten Takalar.Mendeskripsikan pengaruh faktor oseanografi terhadap hasil tangkapan pancing 
ulur yang beroperasi di perairan Selat Makassar. Mendeskripsikan distribusi tangkapan pancing ulur yang beroperasi di perairan Selat Makassar

\section{BAHAN DAN METODE}

\section{Waktu dan Tempat}

Penelitian ini berlansung selama 2 bulan yakni April hingga Juni 2018. Lokasi pengambilan data terletak pada tiga tempat yakni Karang Laisi, Karang Masalima dan di perairan sekitar Pulau Tanakeke dengan jumlah titik sampel sebanyak 42 titik.

\section{Metode Pengumpulan Data}

Metode pengambilan data yang dilakukan dalam penelitian ini terbagi atas tiga metode yakni:

1. Studi Pustaka

Dalam metode ini dilakukan
pengumpulan informasi yang dapat mendukung penelitian ini. Sumber informasi tersebut terdiri dari buku, jurnal serta publikasi hasil penelitian lainnya. Informasi tersebut dijadikan sebagai bahan perbandingan terhadap data lapangan yang diperoleh.

2. Pengamatan Lapangan (observasi)

Pengamatan lapangan dilakukan untuk memperoleh data primer berupa data suhu permukaan laut, kecerahan perairan, salinitas, dan data hasil tangkapan serta beberapa parameter oseanografi lainnya yang diperoleh dengan cara mengikuti kegiatan pengoperasian alat tangkap hand line

\section{Wawancara}

Metode ini dilakukan untuk melengkapi data lapangan dan data sekunder yang dianggap belum lengkap. Dalam metode ini informasi yang diperoleh adalah data biaya operasional, cara penentuan fishing ground, dimensi kapal dan konstruksi alat tangkap bottom handline.

\section{Analisis Data}

a. Peta sebaran SPL dan berat tangkapan. Peta sebaran SPL dan tangkapan berisi informasi tentang letak fishing ground berdasarkan sebaran suhu permukaan laut serta jumlah tangkapan yang diperoleh pada tiap titik penangkapan.

b. Peta sebaran kedalam dan berat tangkapan

c. Peta ini berisi informasi tentang jumlah hasil tangkapan pada setiap titik dalam satuan kilogram. Dalam pembuatan peta ini diperlukan data jumlah berat hasil tangkapan per titik penangkapan. Kemudian selanjutnya dipetakan.

d. Peta sebaran salinitas dan berat tangkapan

e. Peta sebaran salinita dan tangkapan dibuat untuk menghasilkan peta letak tititk-titik penangkapan serta sebaran titik penangkapan berdasarkan peta tersebut.

f. Histogram hubungan tangkapan dan faktor oseanografi

g. Hubungan faktor oseanografi dengan tangkapan pancing ulur dapat dilihat melalui histogram hubungan. Adapun histogram hubungan yang dibuat yakni histogram SPL dan tangkapan, Salinitas dan tangkapan, serta histogram kedalaman dan tangkapan. dalam pembuatan histogram yakni berupa data hasil ekstraksi dari peta sebaran yang dibuat sebelumnya.

h. Ekstraksi peta penangkapan dilakukan dengan bantuan fitur "Extraction" dan "Extract values to point" pada program ArcMap. Selanjutnya data tersebut diolah menjadi histogram hubungan menggunakan aplikasi Origin 85

i. Histogram Frekuensi Pennagkapan 
j. Hasil ekstraksi pada peta kemudian diolah menjadi grafik frequensi penangkapan dengan cara melihat jumlah kemunculan/upaya yang dilakukan pada masing-masing kisaran parameter oseanografi dalam hal ini SPL, salinitas dan kedalaman perairan.

\section{HASIL DAN PEMBAHASAN}

\section{A. Zonasi Daerah Penangkapan Pancing Ulur}

Dalam penelitian ini ditemukan 3 zona daerah pengoperasian pancing ulur oleh nelayan Galesong Selatan seperti pada Gambar 22. Zona I terletak di perairan Pulau Tanakeke pada koordinat $-05^{\circ} 20^{\prime} 02^{\prime \prime}$ LS hingga $-05^{\circ} 42^{\prime} 06^{\prime \prime}$

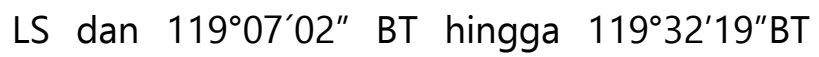

dengan luas area $\pm 70,43$ mil. Adapun zona II terletak di perairan Karang Bone Laisi ditempuh selama \pm 21 jam dari Kota Makassar, zona ini terletak pada koordinat $-05^{\circ} 15^{\prime} 43^{\prime \prime}$ LS hingga $06^{\circ} 32^{\prime} 08^{\prime \prime L S}$ dan $117^{\circ} 58^{\prime} 24^{\prime \prime}$ BT hingga $118^{\circ} 49^{\prime} 51^{\prime \prime} B T$ dengan luas wilayah $\pm 135,46$ mil. Selanjutnya zona III terletak pada koordinat $04^{\circ} 57^{\prime} 22^{\prime \prime} \mathrm{LS}$ hingga $-05^{\circ} 31^{\prime} 45^{\prime \prime} \mathrm{LS}$ dan $117^{\circ} 12^{\prime} 37^{\prime \prime} \mathrm{BT}$ hingga $118^{\circ} 02^{\prime} 29^{\prime \prime} \mathrm{BT}$ dengan luas wilayah $\pm 230,5$ mil.

Ditinjau dari aspek wilayah pemerintahan ketiga lokasi zona tersebut terbagi kedalam wilayah Kabupaten Pangkep dan Takalar. perairan zona I terletak di sekitar Pulau Tanakeke dan termasuk kedalam wilayah Kabupaten Takalar. Adapun zona II dan III termasuk kedalam wilayah Kabupaten Pangkep.

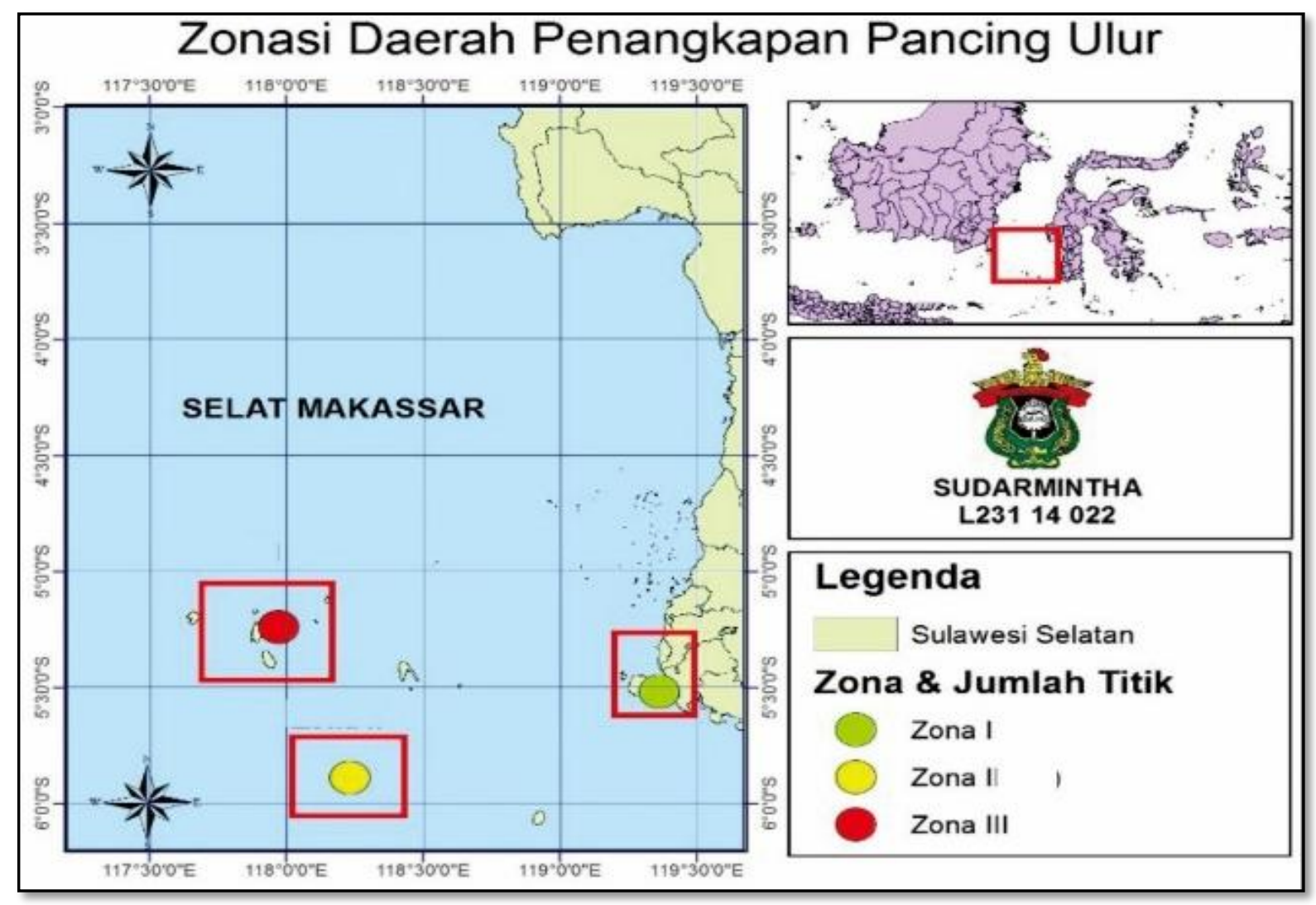

Gambar 1. Zonasi daerah penangkapan handline di perairan Selat Makassar

\section{B. Distribusi Tangkapan Pancing Ulur}

Selama penelitian tidak pernah ditemukan spesies tangkapan yang memiliki dominasi di atas 50\%. Salah satu hal yang diduga mempengaruhi hal tersebut yakni kebiasaan hidup ikan demersal yang senang berbaur 
dengan spesies lain. Menurut Kantun (2014) ikan-ikan demersal yang merupakan target tangkapan pancing ulur memiliki kebiasaan hidup berdampingan dengan spesies lainnya.

Lebih lanjut dikatakan pula bahwa salah satu penyebab tingginya keanekaragaman spesies di terumbu karang adalah variasi habitatnya beragam karena terumbu karang tidak hanya terdiri dari karang saja namun juga terdapat daerah berpasir dan berbatu (Nasir dkk, 2017).

Perbedaan karakter oseanografi pada tiap zona membuat komposisi tangkapan juga berbeda-beda pada tiap tempat. Perbedaan tersebut meliputi aspek jenis maupun ukuran tangkapan. Hal tersebut menandakan adanya pengaruh faktor lingkungan terhadap kehidupan ikan target tangkapan.

Hasil tangkapan pancing ulur yang dioperasikan oleh nelayan di Desa Mangindara

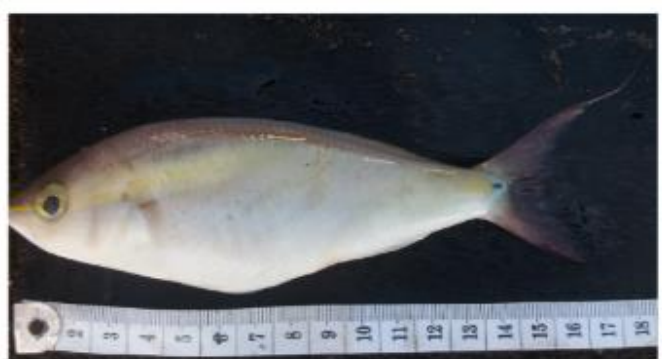

Pentapodus paradiseus

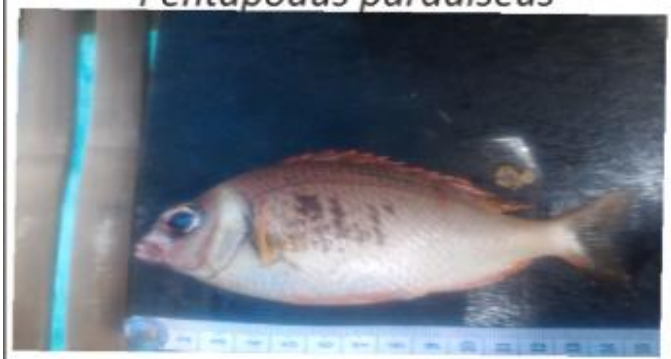

Scolopsis vasmeri didominasi oleh 3 famili yakni Lethrinidae, Serranidae dan Lutjanidae. adapun jenis lain yang ikut tertangkap (by catch) yakni Labridae dan Balistidae. Berikut diuraikan distribusi tangkapan pada masing-masing zona.

\section{Distribusi Tangkapan Zona I}

Hasil tangkapan pancing ulur yang dioperasikan pada perairan sekitar Pulau Tanakeke (zona I) didominasi oleh famili ikan yakni Jangki (Pentapodus paradiseus) Jangki timun (Scolopsis vosmeri), lencam matahari (Lutjanus lentjan) dan jangki pasir (Scolopsis monogramma). Ikan ini banyak tertangkap pada kedalaman < 15 meter dengan tipe substrak berpasir yang ditumbuhi lamun. Adapun tangkapan dominan pada zona I yakni sebagai berikut (Gambar 2) :

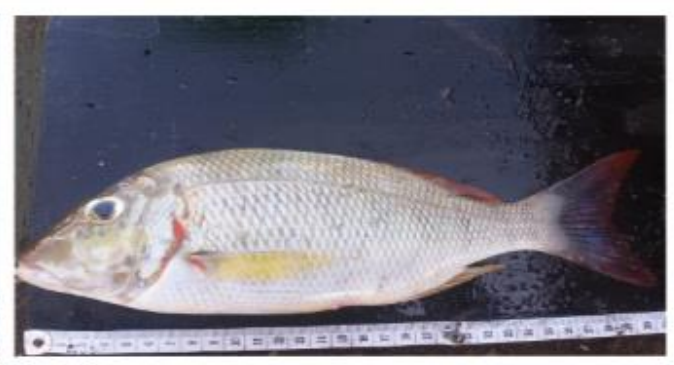

Lethrinus lentjan

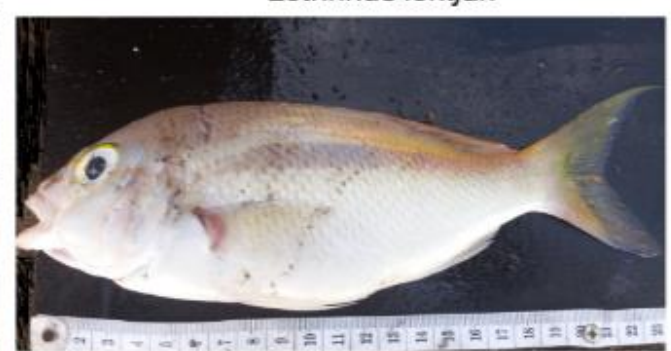

Scolopsis monogramma

Gambar 2. Spesies tangkapan dominan di perairan pulau Tanakeke (zona I)

Spesies Pentapodus paradiseus pada zona I memiliki dominasi $\pm 33,93 \%$ dari total tangkapan, kemudian untuk jenis jangki timun (scolapsis vosmeri) memiliki dominasi sebesar $15,48 \%$ dan jenis lencam matahari (Lethrinus lentjan) sebanyak $17,86 \%$ Sementara untuk spesies jangki pasir (Scolopsis monogramma) memiliki dominasi 20,83 \% dan tangkapan dari spesies lainnya sekitar kurang lebih sebanyak $11,90 \%$. 
Kondisi perairan zona I yang dangkal dengan tipe subsrak lumpur dan pasir membuat dominasi ikan dari famili Nemipteridae banyak tertangkap pada handline yang dioperasikan di lokasi tersebut. Menurut Russsel (1990) dalam Naik (2000) famili Nemipteridae menyukai habitat terumbu karang dangkal ataupun daerah demersal mulai dari kondisi berpasir hingga berlumpur. Berikut disajikan histogram jenis hasil tangkapan yang dominan tertangkap pada zona 1 (Gambar 3).

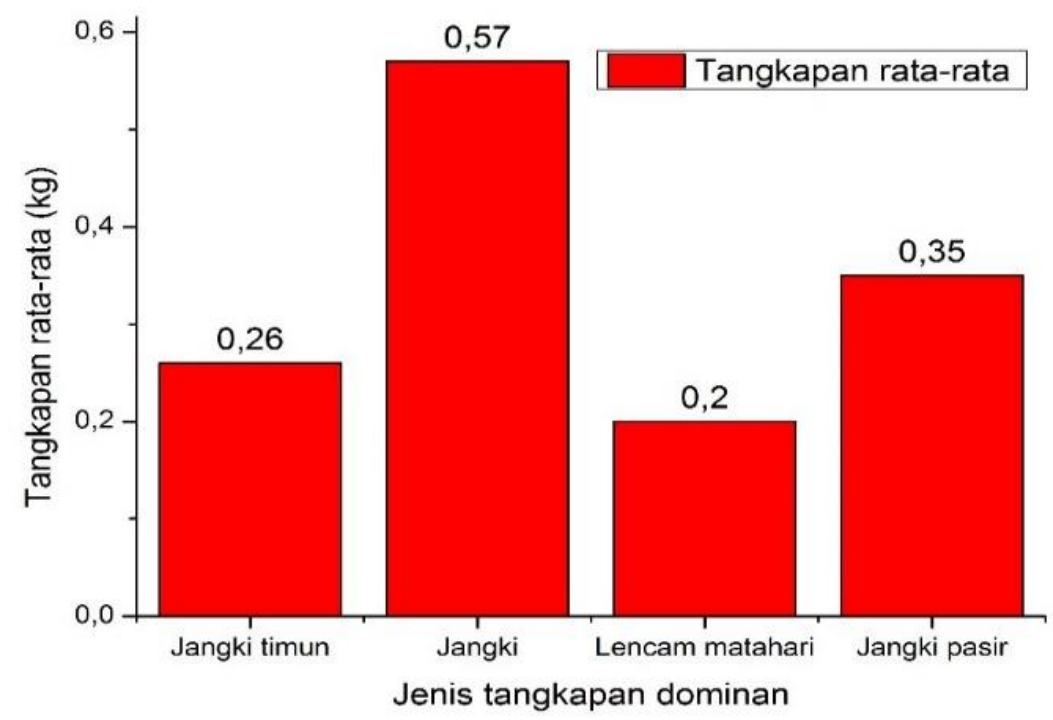

Gambar 3. Histogram berat rata-rata tangkapan pada zona I

Jika ditinjau dari segi ukuran, ikan tangkapan pancing ulur yang dioperasikan pada zona I cenderung berukuran kecil hal ini dipengaruhi oleh tingkat eksplotasi pada zona I cukup tinggi sehingga proses rekruitment ikan tidak berjalan optimal. Tingginya frekuensi penengkapan pada zona I tidak terlepas dari faktor jaraknya yang berada dekat dengan daratan sehingga mudah diakses oleh nelayan penangkap.

Hal tersebut semakin diperburuk oleh tingginya suplay pencemaran dari daratan yang masuk menuju habitat di zona I. Akibatnya ikan- ikan yang tidak mampu melakukan adaptasi akan berpindah atau bahkan mengalami kematian secara massal.

\section{Distribusi Tangkapan Zona II}

Pada perairan zona II ditemukan jumlah spesies tangkapan yang berukuran cukup besar jika dibandingkan dengan zona I, Rata-rata tangkapan pada zona II memiliki panjang total $28,64 \mathrm{~cm}$. hal tersebut dipengaruhi oleh tingkat kesuburan zona II yang cukup tinggi serta tingkat ekspoitasi sumberdaya yang masih rendah mengingat jaraknya yang jauh. 


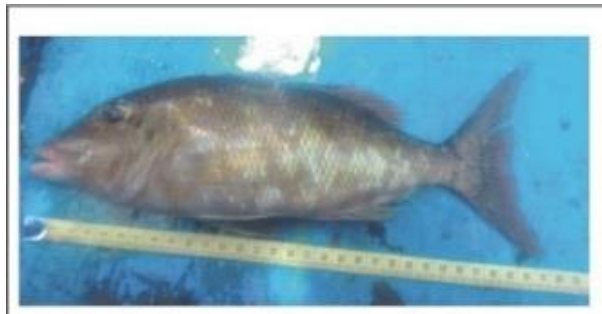

Lethrinus xhantocheilus

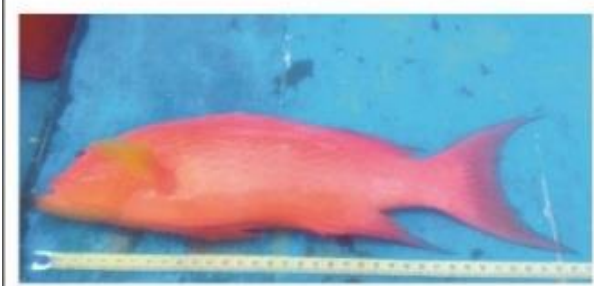

Variola louti

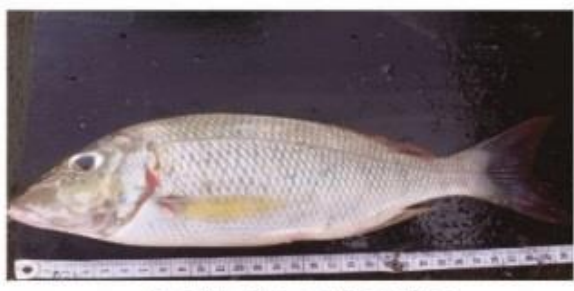

Lethrinus lentjan

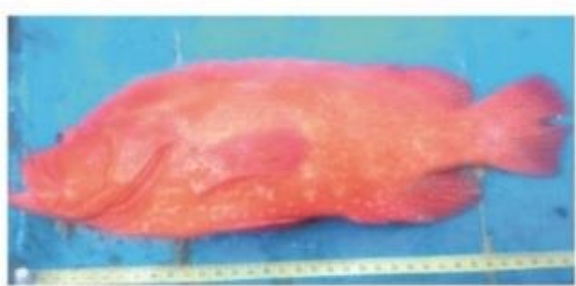

Chepalopholis sonnerati

Gambar 4. Spesies tangkapan dominan pada (zona II)

Ikan yang dominan tertangkap pada zona II dapat dilihat pada Gambar 4. Adapun komposisi jenis tangkapan pancing ulur pada zona II terdiri atas lencam babi (Lethrinus xhantocheilus) 31,24\%, lencam matahari (Lethrinus lentjan) 14,29\%, kerapu ekor gunting (Variola louti) $19,05 \%$ dan kerapu tomat (Chepalopholis sonneratı) 16,38\% serta spesies lainnnya 19,05\%. Pada perairan zona II tidak pernah diperoleh tangkapan jenis kakap merah (Lutjanus sp). Hal ini diduga kondisi oseanografi yang tidak sesuai dengan kondisi oseanografi pada zona II.

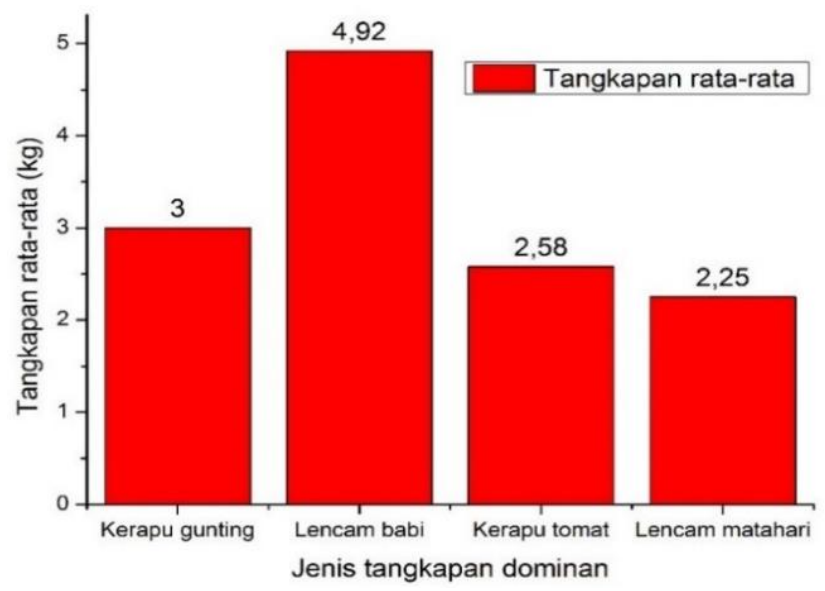

Gambar 5. Histogram berat rata-rata tangkapan pada zona II

3. Distribusi Tangkapan Zona III

Distribusi spesies tangkapan pada zona III memiliki kemiripan dengan tangkapan pada zona II. Diduga hal tersebut disebabkan oleh 
jarak kedua zona ini yang cukup berdekatan sehingga karakter oseanografi pada kedua perairan ini tidak memiliki perbedaan yang

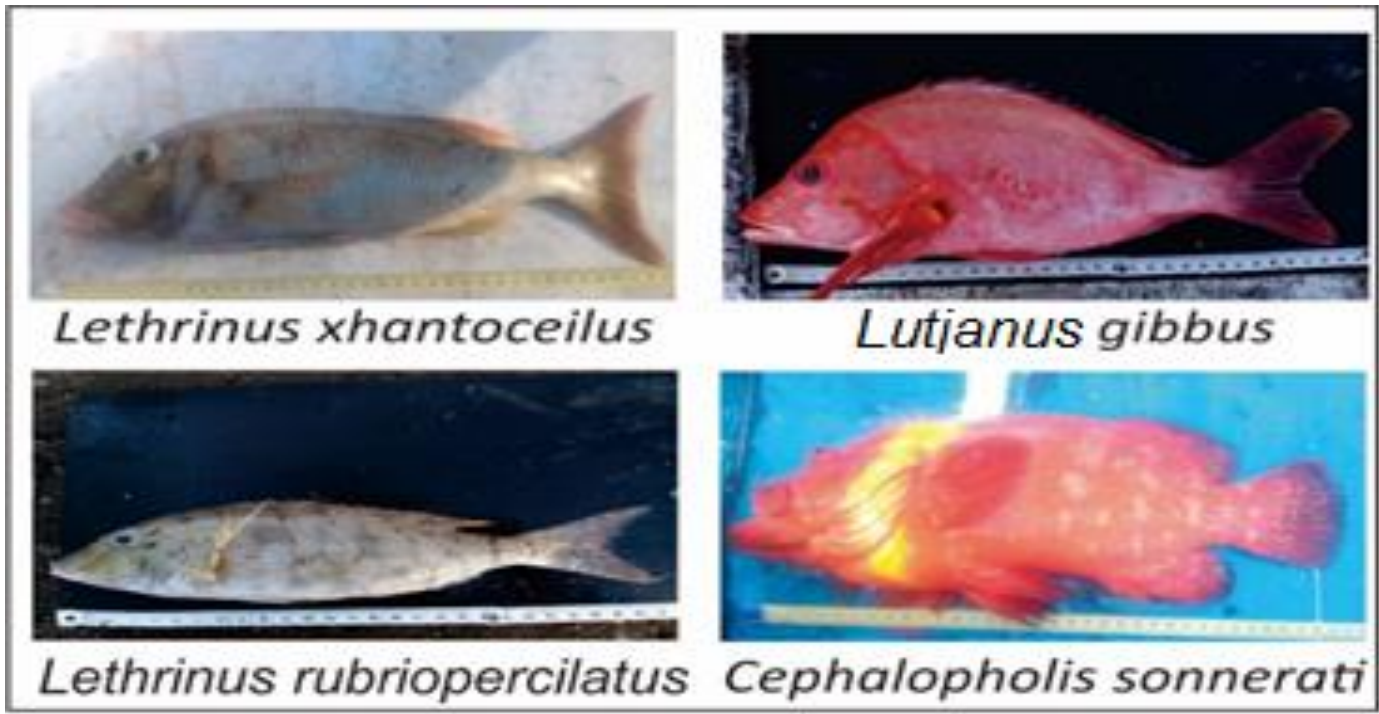

Gambar 6. Spesies tangkapan dominan di Karang Masalima (zona III)

Jika ditinjau dari segi ukuran rata-rata hasil tangkapan pada zona III sedikit lebih besar daripada tangkapan di zona II yakni $36,12 \mathrm{~cm}$ seperti (Gambar 4). Ukuran tangkapan ikan yang tertangkap di zona III cenderung berukuran besar diduga karena kesulitan nelayan dalam mengakses zona tersebut sehingga tingkat eksplotasinya masih rendah. Tingkat eksplotasi yang rendah tersebut memeberikan peluang bagi ikan di lokasi tersebut untuk tumbuh mencapai ukuran maksimal. Tangkapan dominan pada zona III didominasi oleh famili Lethridae, Lutjanidae, dan Serranidae. terlalu mencolok. Dapat dilihat pada Gambar 6 spesies ikan yang dominanan tertangkap pada zona III. pancing ulur yang dioperasikan pada perairan zona III yakni lencam babi (Lethrinus xhantoceilus) 31,82\%, kakap merah (Lutjanus gibbus) 24,70\%, kerapu kuwaci/tomat (Cephalopholis sonnerati) 18,12\% dan lencam merjung (Lethrinus rubrioperculatus) dengan proporsi sebesar 25,36. adapun jenis tangkapan lain terdiri dari jenis guntur (Aprion virescens), pogot (Abalistes spp) dan lain-lain dengan proporsi 9,06\%. Pada Gambar 7 Berikut disajikan histogram jumlah tangkapan rata-rata pada zona III

Adapun komposisi jenis tangkapan

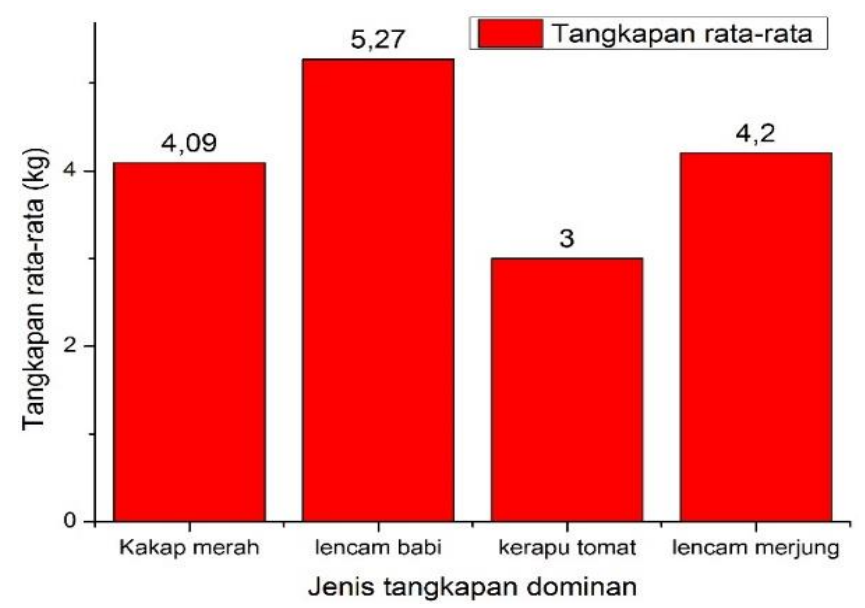

Gambar 7. Histogram berat rata-rata tangkapan pada zona III 
Sama halnya pada zona II bahwa dominasi ikan lencam mencapai persentase paling tinggi diantara semua jenis tangkapan yang ada. Hal ini selain dipengaruhi oleh populasi ikan lencam yang banyak di perairan tersebut, faktor lain yang turut berpengaruh adalah tingkah laku makan (feeding behavior) dari jenis ikan lencam yang bersifat rakus.

Berdasarkan hasil pengamatan lapangan, ditemukan informasi bahwa ikan target tangkapan pancing ulur memiliki waktu/periode makan yang berbeda-beda. Pada jenis lencam (Lethrinus sp) umumnya tertangkap sepanjang hari, sememntara untuk jenis kerapu dominan tertangkap pada waktu pagi hari dan adapun untuk jenis kakap merah (Lutjanus gibbus) banyak tertangkap pada waktu sore menjelang malam. Baskoro dkk (2011) menyatakan jenis ikan kakap yang merupakan target tangkapan handline termasuk ikan buas yang aktif mencari makan, utamanya pada malam hari. Menurut Adrim (1983) Berdasarkan periode aktif mencari makan ikan dapat digolongkan sebagai ikan yang mencari makan pada malam hari (nocturnal), siang hari (diurnal) dan sore hari (crepuscular).
C. Peta Sebaran Parameter Oseanografi \& Tangkapan

Pada suatu perairan parameter oseanografi sebenarnya tidak berdiri sendiri melainkan memiliki keterkaitan (korelasi) antar satu sama lain dalam mempengaruhi kehidupan ikan. Selain mempengaruhi kehidupan ikan (fisiologi), faktor oseanografi juga sangat berpengaruh langsung dalam proses pengoperasian alat tangkap pada suatu wilayah perairan..

1. Hubungan Suhu Permukaan Laut dan Tangkapan

Suhu permukaan laut (SPL) dapat digunakan sebagai salah satu cara untuk menduga keberadaan organisme di suatu perairan, khususnya ikan. Pengaruh suhu terjadi secara langsung terhadap kehidupan di laut terkait laju fotosintesis tumbuh-tumbuhan dan fisiologi hewan air (Iwan, 2018).

Menurut Baskoro Dkk (2010) ikan akan sangat peka terhadap perubahan suhu walau hanya sebesar $0,03^{\circ} \mathrm{C}$ sekalipun. Kecepatan makan, metabolisme dan pertumbuhan ikan bukan hanya dipengaruhi oleh ketersedian makanan semata, Suhu yang terlalu tinggi, tidak normal, dan tidak stabil ternyata akan mengurangi kecepatan makan ikan. 


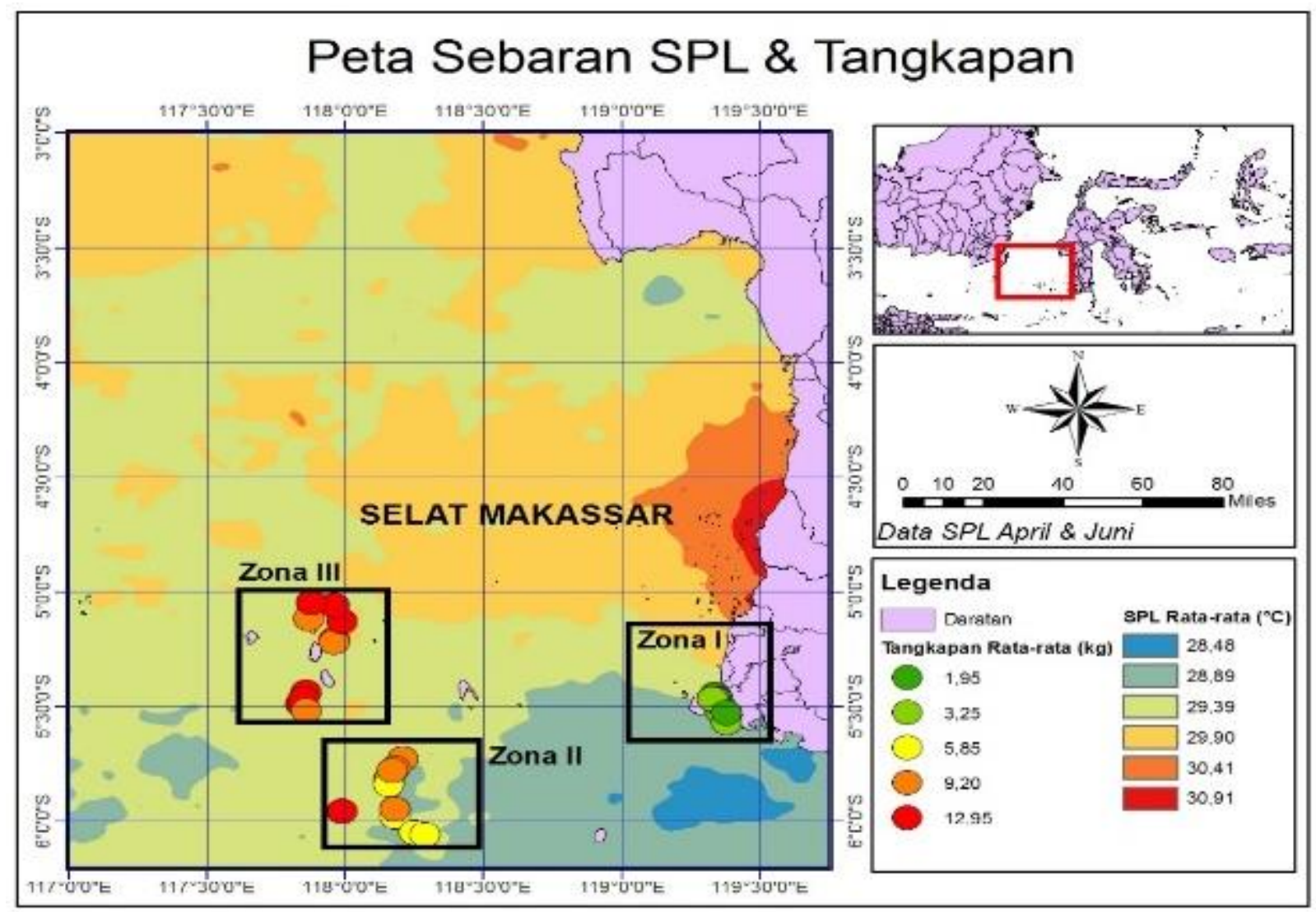

Gambar 8. Peta sebaran SPL dan tangkapan pancing ulur di perairan Selat Makassar

Pada Gambar 8 disajikan variasi kisaran SPL rata-rata di perairan Selat Makassar pada bulan april dan juli yang memperlihatkan adanya variasi sebaran SPL yang cukup rendah. Rendahnya variasi SPL di perairan Selat Makassar dipengaruhi oleh tingkat pemanasan yang terjadi pada lapisan permukaan laut cenderung merata di perairan tersebut. Menurut Cahya (2015) untuk perairan tropis seperti perairan Indonesia variasi suhu yang terjadi sangat kecil. ini dipengaruhi oleh tingkat penerimaan panas matahari yang cenderung merata pada setiap tempat yang terletak di khatulistiwa. Sementara Wyrtki (1961) dalam Baskoro dkk (2010) mengatakan khusus untuk perairan Indonesia yang merupakan perairan tropis, oleh sebab itu masalah suhu tidak jelas memberikan gambaran bagaimana pengaruhnya terhadap bidang perikanan. Hal tersebut mungkin sekali disebabkan karena perairan Indonesia yang juga merupakan perairan tropis mempunyai variasi tahunan suhu yang kecil saja jika dibandingkan dengan beberapa perairan lainnya (subtropis). 
a

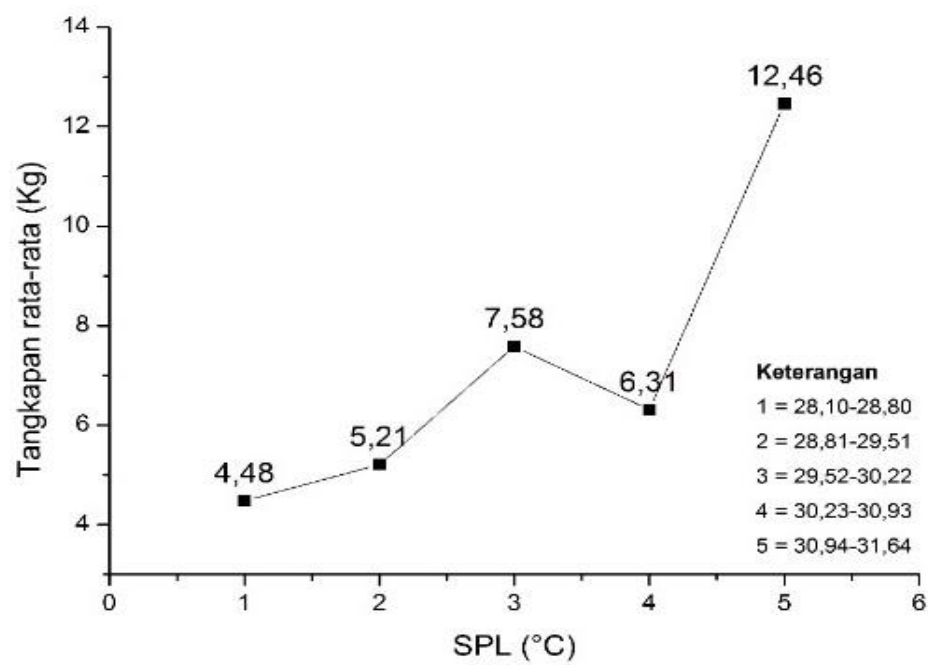

b

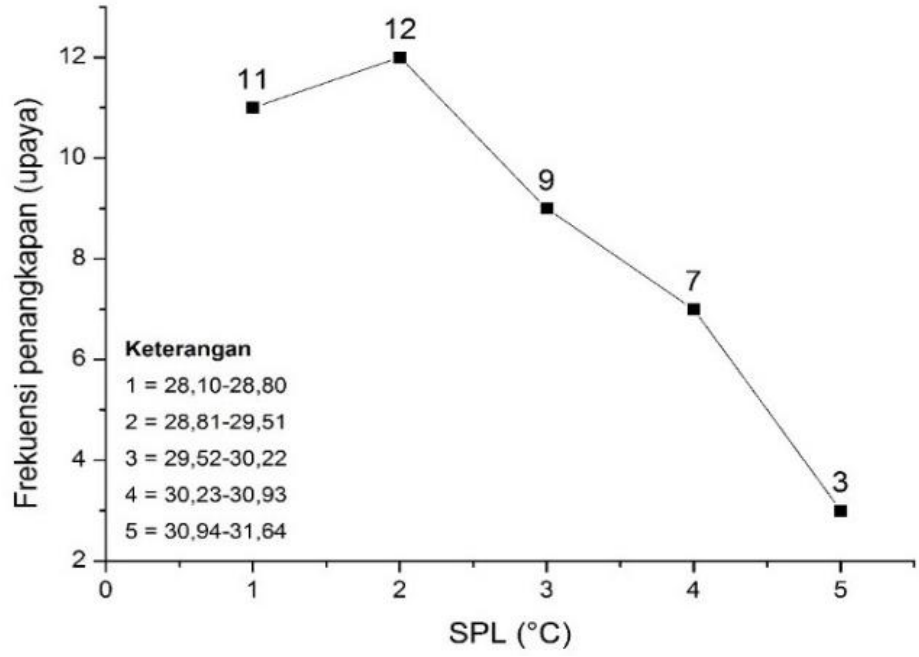

Gambar 9. Histogram a. hubungan SPL dan tangkapan, b. SPL dan upaya penangkapan

Berdasarkan hasil penelitian (Gambar 9a) kisaran suhu permukaan laut untuk daerah penangkapan pancing ulur yang menangkap ikan demersal yakni $28,10^{\circ} \mathrm{C}-31,64^{\circ} \mathrm{C}$. Menurut Mubarak Dkk (2014) suhu di perairan Tarakan yang disukai gerombolan ikan demersal adalah $28^{\circ} \mathrm{C}$. Dalam penelitian ini tangkapan optimum diperoleh pada kisaran SPL $30,94^{\circ} \mathrm{C}-31,64^{\circ} \mathrm{C}$ atau sedikit lebih tinggi dari hasil penelitian sebelumnya. Tingginya hasil tangkapan pada kisaran suhu yang lebih tinggi disebabkan oleh laju metabolisme ikan yang berlangsung cepat pada kisaran suhu tinggi sehingga berpengaruh terhadap tingkah laku makan ikan target (feeding behavior).

Frekuensi upaya penangkapan tertinggi terjadi pada kisaran suhu $28,10^{\circ} \mathrm{C}-29,50^{\circ} \mathrm{C}$ dengan total upaya 23 kali seperti pada Gambar 9b Selama penelitian ditemukan bahwa tangkapan optimum biasanya diperoleh pada dua selang waktu yakni pagi dan sore hari. Diduga pada waktu tersebut ikan target tangkapan aktif mencari makan. Menurut Adrim (1983) Berdasarkan periode aktif mencari makan ikan karang dapat digolongkan sebagai ikan yang mencari makan pada malam hari (nocturna), siang hari (diurna) dan sore hari (crepuscular).

\section{Sebaran Kedalaman dan Tangkapan}

Hasil pengujian secara statistik menunjukkan bahwa kedalaman merupakan parameter yang berpengaruh signifikan terhadap distribusi tangkapan pancing ulur. 
Bagi ikan demersal kedalaman memiliki pengaruh terhadap kondisi fisiologi serta keberadaan terumbu karang yang merupakan habitat mereka.

Menurut Tombokan dkk (2017).ekosistem terumbu karang merupakan tempat hidup, tempat mencari makan (feeding ground), tempat memijah (spawning ground) dan daerah asuhan (nursery ground) untuk berbagai jenis ikan dan biota laut lainnya. Bagi jenis ikan demersal terumbu karang merupakan tempat mereka menggantungkan hidupnya. Sehingga keberadaan ikan demersal sangat bergantung pada keberadaan terumbu karang pada suatu perairan (Ghufran \& Kordi, 2010). Pada Gambar 10 Berikut disajikan peta sebaran kedalam perairan Selat Makassar dan daerah pengoperasian pancing ulur.

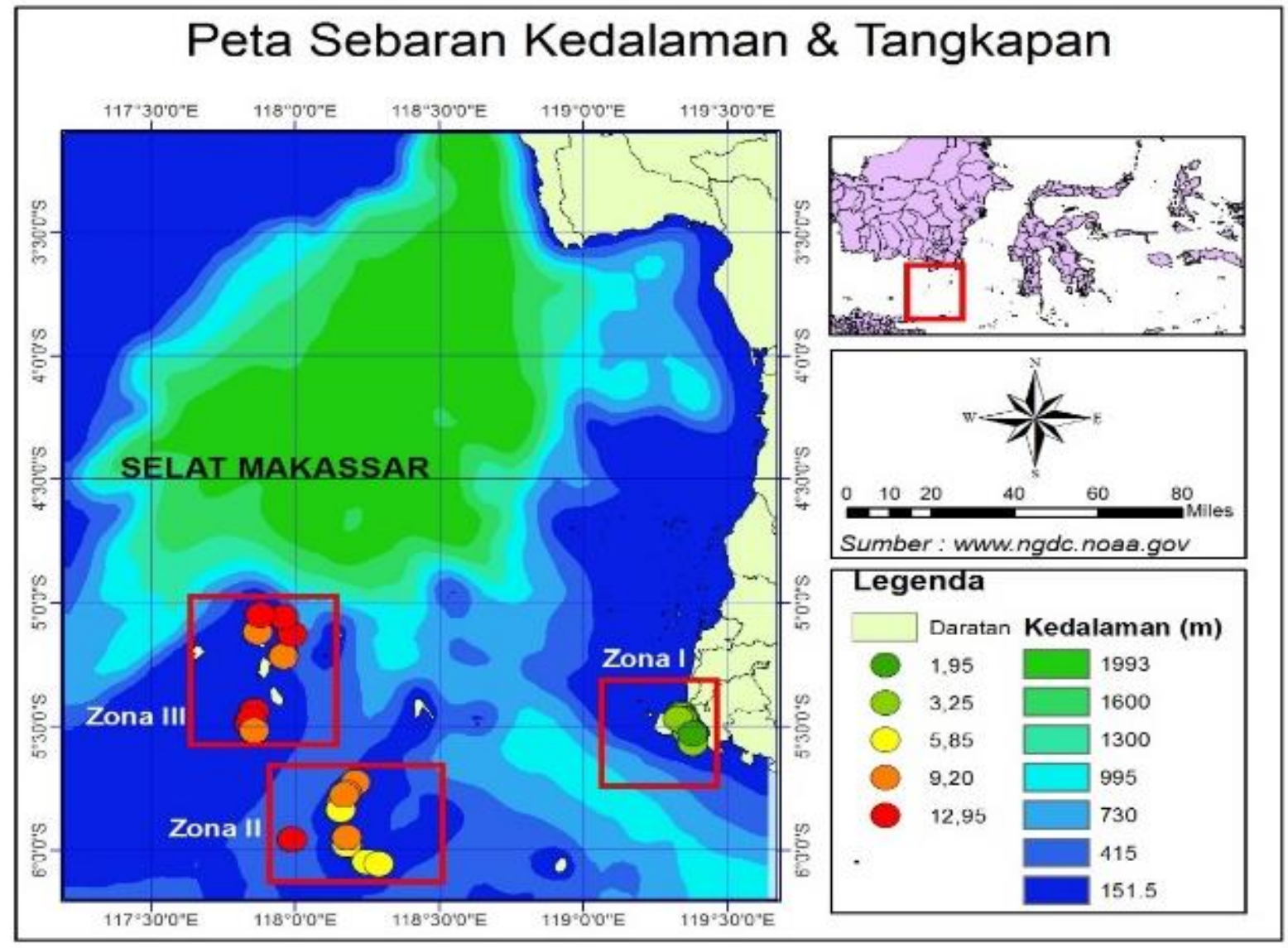

Gambar 10. Peta sebaran kedalaman dan tangkapan handline di perairan selatan Selat Makassar

Kisaran kedalaman untuk daerah penangkapan pancing ulur yang menangkap ikan demersal di perairan Selat Makassar berada pada kisaran 9,20 m - 47,80 m (Gambar 11a). pada kisaran kedalaman tersebut komunitas ikan demersal cukup berlimpah dikarenakan pada kedalaman tersebut terumbu karang yang merupakan habitat alami ikan target tangkapan pancing ulur dapat berkembang. Menurut Ghufran \& Kordi (2010) terumbu karang tidak dapat berkembang di perairan yang lebig dalam dari 50-70 meter.

Rata-rata berat tangkapan optimum pancing ulur yang beroperasi di perairan Selat Makassar diperoleh pada kisaran kedalaman $32,0 \mathrm{~m}$ - .47,8 m. Adapun rata-rata tangkapan terendah ditemukan pada kedalaman 9,2 m 16,7 meter.

Pada Gambar 11 Berikut disajikan grafik hubungan antara sebaran tangkapan pancing ulur dengan distribusi parameter kedalaman 
a

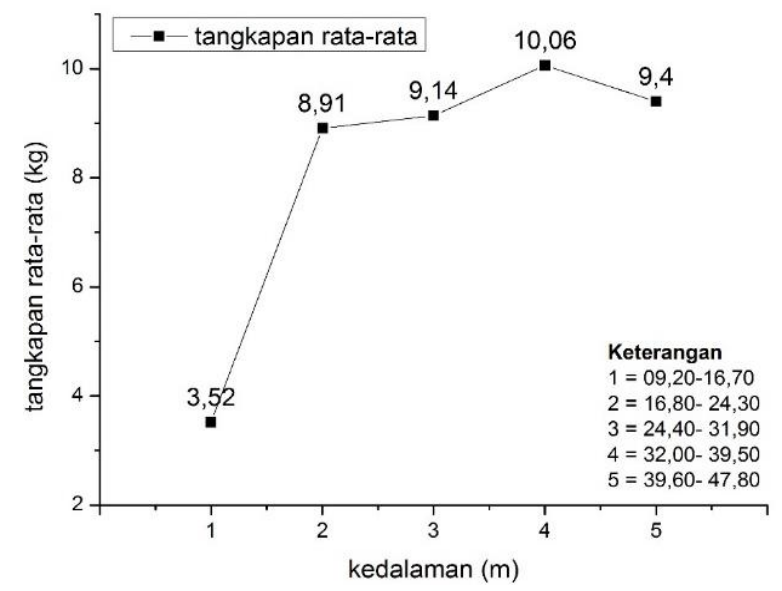

$\mathrm{b}$

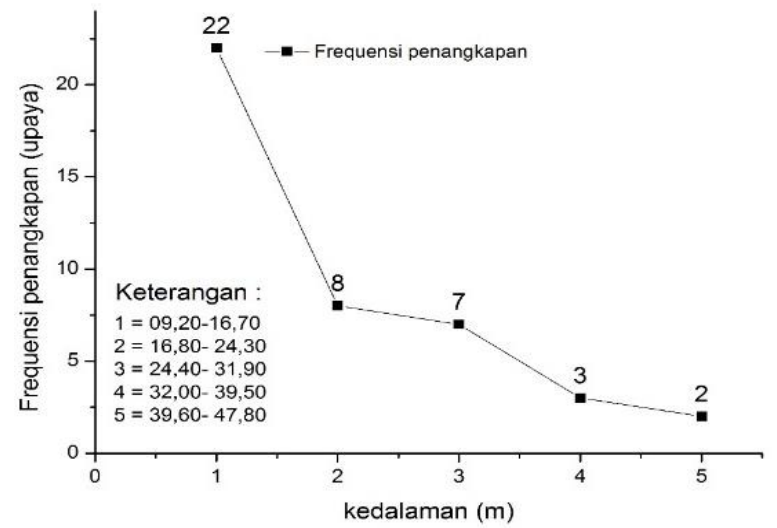

Gambar 11. Histogram a. Hubungan kedalaman dan tangkapan, b. Frekuensi penangkapan \& kedalaman

Berdasarkan parameter kedalaman ditemukan adanya perbedaan distribusi hasil tangkapan baik dari aspek sebaran jenis maupun jumlah dan ukuran. Menurut Nasir dkk (2017) kelimpahan ikan di setiap stasiun/lokasi memiliki nilai yang relatif berbeda. Dalam penelitian ini (Gambar 11a) ditemukan adanya korelasi (hubungan) yang bersifat positif antara kedalaman dan tangkapan

Pada kisaran kedalaman yang relatif dangkal (9,2 m-16,70 m) jumlah ikan yang tertangkap cukup banyak dan didominasi oleh ikan-ikan berukuran kecil $(\leq 15 \mathrm{~cm})$ dari jenis ikan jangki (Scolopsis \& Pentapodus). Sementara pada kisaran kedalaman $17 \mathrm{~m}$ 47,50 m kuantitas ikan yang tertangkap relatif sedikit namun berukuran besar dan didominasi oleh jenis ikan dari famili lethridae dan lutjanidae. Hal ini sesuai dengan pendapat Muandri dkk (2013) Kakap merah (/utjanidae) umumnya tertangkap pada kedalaman dasar antara 40-50 meter dengan substrat sedikit karang dan salinitas 30 -33 ppt serta suhu antara $\left(5-32^{\circ} \mathrm{C}\right)$.

Selama penelitian ditemukan frekuensi penangkapan tertinggi berada pada kisaran kedalaman 9,2 m -16,70 m dengan jumlah total upaya 20 titik. Tingginya upaya penangkapan pada kisaran kedalaman 9,2 m -16,70 m terjadi karena fishing ground dengan kedalaman tersebut memiliki jarak yang tidak terlalu jauh dari fishing base sehingga untuk mengurangi resiko dari kondisi cuaca yang berbahaya, nelayan lebih memilih untuk menangkap di perairan yang dekat dan mudah diakses sementara untuk fishing ground yang jauh dengan kisaran kedalaman $<17 \mathrm{~m}-47,8 \mathrm{~m}$ diakses ketika cuaca betul-betul aman.

3. Sebaran Salinitas dan Tangkapan

Semua jenis ikan mempunyai salinitas optimal untuk hidupnya. Ikan akan melakukan 
aklimatisasi bila terjadi perubahan salinitas yang ekstrem. Secara fisiologis salinitas berkaitan erat dengan penyesuaian tekanan osmotik ikan (Rohman, 2013 dalam Mubarak Dkk. 2014). Bagi ikan demersal yang merupakan target tangkapan pancing ulur, salinitas memiliki pengaruh yang besar terhadap perkembangan terumbu karang yang merupakan habitat mereka.

Di wilayah perairan Selat Makassar yang merupakan lokasi pengoperasian pancing ulur ditemukan kisaran salinitas rata-rata pada bulan april dan mei berkisar antara 31,06 ppt - 33,47 ppt (Gambar 12). adanya perbedaan sebaran salinitas pada setiap tempat di perairan Selat Makassar diduga dipengaruhi oleh beberapa faktor antara lain letak geografis. Menurut Lasniroha (2007) sebaran salinitas di laut dipengaruhi oleh berbagai faktor seperti pola sirkulasi air, penguapan (evaporasi) curah hujan (presipitasi) dan aliran sungai (run off).

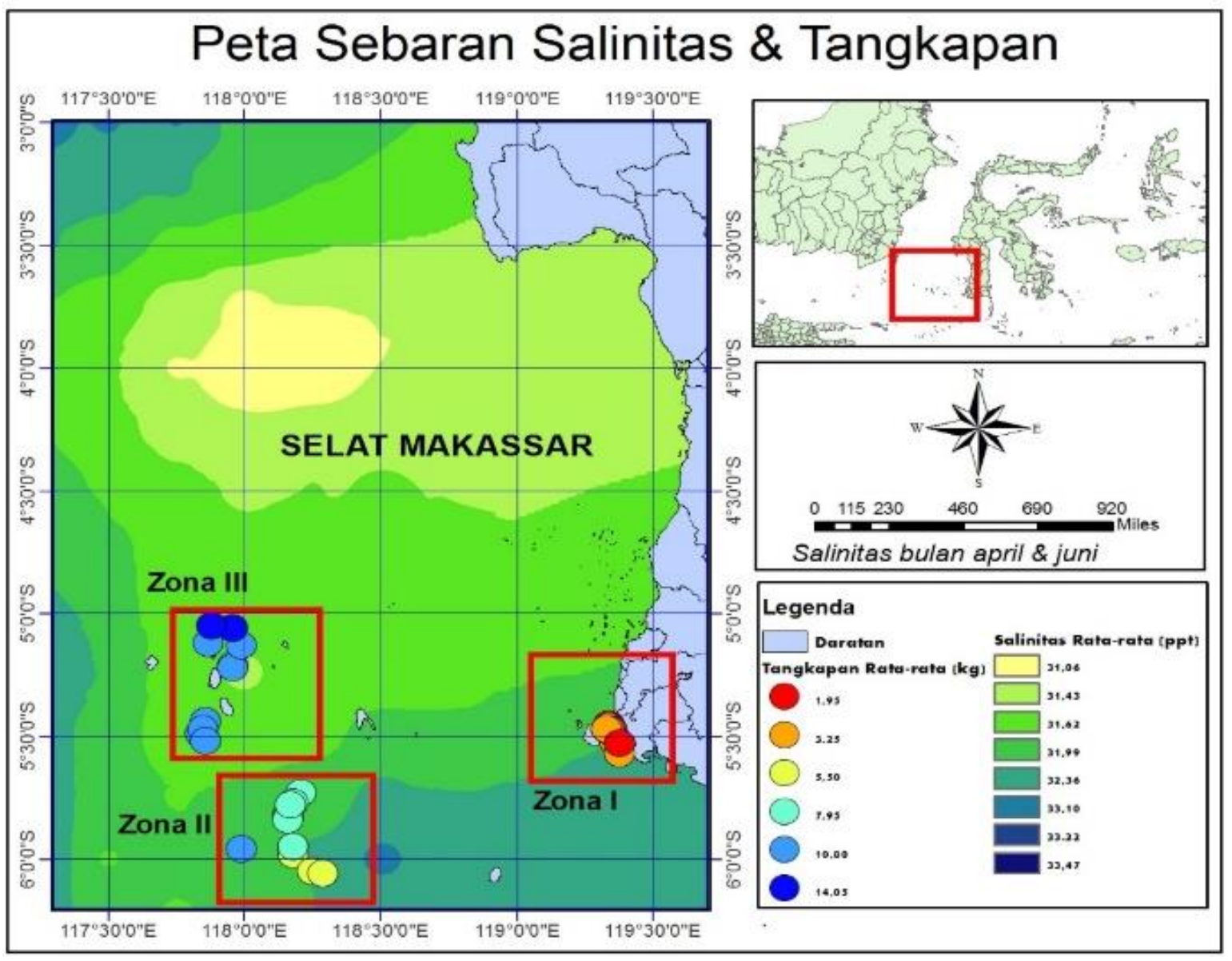

Gambar 12. Peta sebaran salinitas dan tangkapan pancing ulur di perairan Selat Makassar

Untuk wilayah fishing ground pancing ulur yang dioperasikan dalam penelitian ditemukan tersebar pada kisaran salinitas perairan 31,40 ppt - 32,23 ppt (Gambar 13a). Adapun rata-rata tangkapan optimum pancing ulur ditemukan pada kisaran salinitas 31,40 ppt - 31,60 ppt dengan perolehantangkapan ratarata $11,9 \mathrm{~kg}$. Sementara untuk rata-rata tangkapan minimum diperoleh pada kisaran salinitas 32,02 ppt - 32,23 ppt dengan rata-rata perolehan tangkapan 3,5 kg (Gambar 11a). Hal ini memperlihatkan adanya hubungan korelasi negatif antara salinitas dengan tangkapan pada pancing. 
Menurut Iwan (2018) Penangkapan ikan demersal di perairan Tarakan (Selat Makassar) dilakukan pada kisaran salinitas 32.61\%o $32.81 \%$ o. dalam penelitian ini ditemukan frekuensi penangkapan tertinggi berada pada kisaran salinitas 32,03 ppt - 32,23 ppt dengan frequensi penangkapan 26 upaya (Gambar 13b).
Tingginya upaya penangkapan pada kisaran salinitas 32,03 ppt - 32,23 ppt terjadi karena pada saat pengumpulan data curah hujan di zona II \& III cukup tinggi dan memiliki cuaca kurang bersahabat. Sehingga salinitas di zona II \& III menjadi rendah akibatnya kegiatan penangkapan terkonsentrasi pada zona I.

a

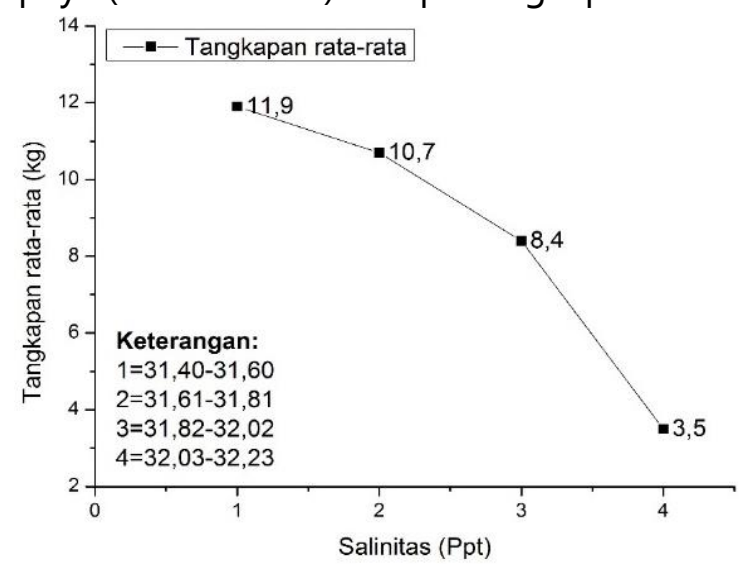

b

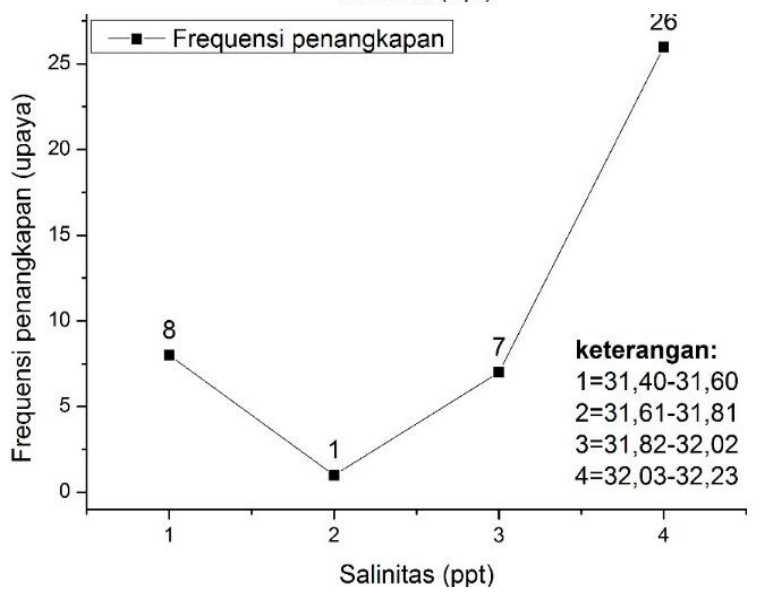

Gambar 13. Histogram (a) hubungan salinitas dan tangkapan rata-rata, (b) frekuensi penangkapan \& salinitas

\section{KESIMPULAN}

Berdasarakan pada hasil penelitian yang dilakukan diperoleh kesimpulan sebagai berikut:

1. Daerah pengoperasian pancing ulur di Perairan Selat Makassar terbagi kedalam tiga zona lokasi yakni Pulau Tanakeke (zona I), Karang Bone Laisi (zona II), Karang Masalima (zona III).

2. Faktor oseanografi perairan khususnya kedalaman setiap zona memiliki pengaruh terhadap distribusi jenis dan ukuran ikan hasil tangkapan pada alat tangkap pancing ulur

3. Jenis ikan lencam dapat ditemukan pada semua zona penangkapan adapun jenis kakap merah hanya dapat ditemukan pada zona II dan jenis kerapu ekor gunting hanya terdapat di zona II.

\section{DAFTAR PUSTAKA}

Adityarini.S, Asriyanto, dan Pramonowibowo. 2012.

Pengaruh

Penggunaan Perbedaan Konstruksi Mata Pancing 
dan Jenis Umpan pada Pancing Ulur Terhadap Hasil Tangkapan di Kawasan Zona Pemanfaatan Perikanan Tradisional Taman Nasional Karimunjawa. Journal of Fisheries Resources Utilization Management and Technology. 1 (1); $97-$ 107.

Adrim M.1993. Metodologi penelitian ikan ikan karang. Dalam Materi Kursus Pelatihan Metodologi Penelitian Penentuan Kondisi Terumbu Karang. Pusat Penelitian dan Pengembangan Oseanologi-LIPI, Jakarta

Allen, G. 1999. Marine Fishes of South-East Asia. Australia: Periplus Edition (HK).Ltd.

Anggawangsa,R.F. 2008. Pengaruh Perbedaan Penggunaan Bentuk Mata Pancing terhadap Hasil Tangkapan Layur (Trichiurus Sp.) Di Palabuhanratu. [Skripsi]. Departemen Pemanfaatan Sumberdaya Perikanan, Fakultas Perikanan dan Ilmu Kelautan. Institut Pertanian Bogor.

Ariawan. W, dan Dedi. 2015. Analisis Hasil Tangkapan Pancing Ulur (Hand Line) Pada Rumpon Portable Di Perairan Selatan Palabuhanratu Jawa Barat. [Skripsi]. Departemen Pemanfaatan Sumberdaya Perikanan, Fakultas Perikanan dan Ilmu Kelautan. Institut Pertanian Bogor, Bogor.

Arief M. 2004. Aplikasi Data Satelit Resolusi Rendah dan SIG Untuk Analisa distribusi Spatial zona potensi penangkapan ikan di selat makassar periode Juli-Agustus 2004. [Skripsi]. Pare-Pare.

Assa D.J, Wagei.Th.B, dan Boneka.F.B. 2015. Jenis Jenis Ikan Di Padang Lamun Pantai Tongkaina. Jurnal pesisir dan Laut Tropis. 2(1): 53-61

Baskoro S.M, Taurusman A. Sudirman. 2011. Tingkah Laku Ikan Hubungannya dengan IImu dan Teknologi Perikanan

Tangkap. Lubuk Agung, Bandung

Cahya.N.C, Setyohadi.D, dan Surinati.D. 2016. Pengaruh Parameter Oseanografi Terhadap Distribusi Ikan. Oseana.1(4): 1-14.

Ghufran M. H., Kordi. K. 2010. Ekosistem Terumbu Karang. [buku] Rineka Cipta. Jakarta.

Iwan. 2018. Pemetaan Daerah Penangkapan Ikan Demersal Di Perairan Tarakan Kalimantan Utara. [Skripsi] Departemen Perikanan, Universitas Hasanuddin, Makassar.

Kantun.A, Harianti, Harijo.S. 2014. Respon Ikan Demersal Dengan Jenis Umpan Berbeda Terhadap Hasil Tangkapan Pada Perikanan Rawai Dasar. Jurnal Balik Diwa. 5(1) :30-35.

Lasniroha. 2007. Perbandingan Pendugaan Densitas Ikan Demersal Dengan Metode Hidroakustik Bim Terbagi Dan Metode Swept Area Di Perairan Laut Jawa. Bogor.

Muandri.N, Asriyanto, dan Yulianto.T. 2013. Hubungan Jenis Umpan Dan Ukuran Mata Pancing Alat Tangkap Rawai Dasar Terhadap Hasil Tangkapan Ikan Kakap (Lutjanus Sp) Di Perairan Pasir, Kebumen. Journal of Fisheries Resources Utilization Management and Technology. 2 (3) : 82-89.

Mubarak, Mulyadi.A, Susilawati, 2014. Analisis Sebaran Schooling Ikan Demersal Di Perairan Tarakan Kalimantan Utara Menggunakan Metode Hidroakustik. [Skripsi]. Fakultas Perikanan Dan Ilmu Kelautan. Universitas Riau.

Nahdya.N, Farhum. A.St, Jaya.I. 2014. Keragaman Jenis Kapal Perikanan Di Kabupaten Takalar. Jurnal IPTEKS PSP.1 (3) : 81-94. 
Nasir.M, Zuhal.M, dan Ulfah.M. 2017. Struktur komunitas ikan karang di perairan Pulau Bate Kecamatan Peukan Bada Kabupaten Aceh Besar. Bioleuser.1 (2) :76-85

Nuriah H. Hidayah Z. Syah F. A. Analisis Parameter Fisika Kimia Di Perairan Sumenep Bagian Timur Dengan Menggunakan Citra Landsat TM5. Jurnal Kelautan. 3 (2) :132-138.

Oktafiani R. Asriyanto, Pramonowibowo. (Tahunnya Mana). Pengaruh Perbedaan Konstruksi Mata Pancing Dan Jenis Umpan Terhadap Hasil Tangkapan Kakap Merah (Lutjanus Argentimaculatus) Dengan Pancing Ulur (Hand Line) Di Perairan Cirebon Cangkol, Jawa Barat. Journal of Fisheries Resources Utilization Management and Technology. 2 (2). :113-123.

Pangalila F. P. T. 2015. Status Hasil Tangkapan Perikanan Pancing Dasar Di Perairan Teluk Buyat. Jurnal IPTEKS PSP. 2 (3) : 238-247

Said, 2015. Sentra Produksi Perikanan Takalar. Dinas Kelautan Dan Perikanan Kabupaten Takalar. 